\title{
Mechanism and challenges associated with adaptation and evolution of drug-resistant bacteria: an overview
}

\author{
Shikha Kapil, Tarun Kumar, Vipasha Sharma* \\ University Institute of Biotechnology, Chandigarb University, Gharuan Mohali (Punjab) Pin: 140413, India
}

Received 22nd April 2019 / Accepted 27th February 2020

\begin{abstract}
Antimicrobial resistance is one of the leading challenges in the human healthcare segment. Advances in antimicrobial resistance studies have revealed various intrinsic, adaptive or acquired factors to be involved for pathogenicity. Antimicrobial agents are either bactericidal or bacteriostatic in action and prescribed according to the mode of action. Various factors are confined for the antimicrobial activity of these agents via biochemical, mechanical, physiological and molecular mechanisms. Microbial cell expresses a number of alternates responsible for the evolution of resistance against these agent activities involving cell surface modifications, enzyme inhibitions, modifications in efflux system, protein carriers and mutations in nucleic acids. Apart from this, the successful adaptations of such microbes have also been observed with the transfer of responsible genes through miscellaneous operations such as vertical evolution, horizontal gene transfer, co-selection, compensatory and random mutation. In addition, alterations or modifications in biochemical and physiological mechanisms at cellular levels are also responsible for antibiotic resistance. This article briefly shows the present scenario of antimicrobial resistance and the alternatives to overcome this global issue in future.
\end{abstract}

Keywords: Antimicrobial agents, antimicrobial resistance, multidrug resistance

\section{INTRODUCTION}

Antimicrobial resistance (AMR) is the capability of disease-causing microorganisms such as bacteria, viruses and parasite to survive in the presence of antimicrobials such as antibiotics, antiviral and antimalarial. Moreover, this AMR has been long perceived and is becoming an immense task to oversee (Antimicrobial resistance, 2017). World Health Organization (WHO) has published their single ever catalogue of antibiotic resistance "priority pathogens" - a catalogue of 12 families of bacteria which present the most serious danger to human health. According to the need, WHO in their catalogue enlisted antibiotic into three major groups on the basis of priority: critical, high and medium priority
(Table 1). These bacteria have been turn out to be resistant to a great amount of antibiotic (WHO, 2017).

The recent data generated by WHO has presented most commonly reported resistant isolates such as Escherichia coli, Klebsiella pneumoniae, Staphylococcus aureus and Streptococcus pneumoniae. Around $82 \%$ of bloodstream infection resistant isolates are present globally and shows to the most commonly used antibiotics. For penicillin and ciprofloxacin, the suspected proportion of resistant isolates fall between the range of $0-51 \%$ and 8-65\% respectively (World Health Organization, 2018). Antibacterial resistance is a consortium of worldwide challenges that

*Author for correspondence: Vipasha Sharma, University Institute of Biotechnology, Chandigarh University, Gharuan Mohali (Punjab) Pin: 140413 India. Email - sharma.vipasha@gmail.com 
interrelates with high morbidity and mortality rate. Gram-positive and negative bacteria are using multifaceted approaches and becoming more reluctant to antibiotics. The dramatic increase in resistance emerges due to over usage of conventional broad-spectrum antibiotics, poor/unhealthy sanitary approaches and unhealthy environmental conditions. There are global issues which are associated with bacterial infection and emerging diseases. Lack of curative approaches, shortage of potential drugs and fewer novel antibiotics needs more consideration to overcome resistance challenges (Akova, 2016). Today's need for finding novel strategies to combat antimicrobial resistance is a major health care challenge (Mühlen \& Dersch, 2015). Many crucial measures taken by WHO, has been leading many health care industries toward the seriousness of resistance and development of preventive measures against resistance (Chellat et al., 2016). Establishment of updated epidemiological data and routine surveillance of resistance status is a useful approach not only in combating diseases but also for the development of a novel/potent medicines ( $\mathrm{Li} \&$ Webster, 2018). According to a survey, researchers have found a $65 \%$ rise in antibiotic usage till the year 2000-2015. In developing countries, greater access to antibiotics has lead resistance at the global level (van Hoek et al., 2011). According to the 2014 analysis report, estimated deaths due to antibiotic resistance were half-million per year that could increase to several million by the year 2050 (Editor, 2018). According to a recent data report, India, Brazil and Vietnam have the highest diversity in resistant genes as compare to New Zealand and Australia. Researcher in their survey also reported antimicrobial resistance emergence due to the poor sanitary condition and individual health status (Science Daily, 2019).

Table 1. World Health Organization (WHO) priority pathogens list for the research and development of new antibiotics.

\begin{tabular}{|c|c|c|c|}
\hline Pathogens & Antibiotics & Resistant genes & Priority \\
\hline Acinetobacter baumannii & \multirow[t]{2}{*}{ carbapenem-resistant } & $\begin{array}{l}\text { OXA-23 and OXA-51 } \beta \text {-lactamase, blaVIM, PER-1-like and } \\
\text { GES-5 (Ibrahim, 2019) }\end{array}$ & \multirow{5}{*}{ Critical } \\
\hline Pseudomonas aeruginosa & & $\begin{array}{l}\text { NDM, VIM, IMP and OXA-48 (Jabalameli et al., 2018) } \\
\text { glnK and } f_{s t K} \text { (Alvarez-Ortega et al., 2011) }\end{array}$ & \\
\hline \multirow{2}{*}{ Enterobacteriaceae } & carbapenem-resistant & NDM, VIM, IMP and OXA-48 (Jabalameli et al., 2018) & \\
\hline & ESBL-producing & $\begin{array}{l}\text { BlactX-м-15 and BlactX-м-2 (Bevan et al., 2017), BlactX-Ms and } \\
\text { BlakPCs (Mathers et al., 2015), ISEcp1-BlactX-M-9-like-IS903 } \\
\text { and ISEcp1-BlactX-M-1-like-OrF477 (Zhao \& Hu, 2013) }\end{array}$ & \\
\hline Entercoccus faecium & vancomycin-resistant & $\begin{array}{c}\operatorname{VanR}, \operatorname{Van} A, \operatorname{Van} Z, \operatorname{VanX}, \operatorname{Van} S, \operatorname{VanH}, \operatorname{VanD} \text { and } \\
\operatorname{Van} C \text { (Ranotkar et al., 2014) }\end{array}$ & \\
\hline Staphylococcus aureus & $\begin{array}{l}\text { methicillin-resistant, } \\
\text { vancomycin- } \\
\text { intermediate and } \\
\text { resistant }\end{array}$ & $\begin{array}{c}m e c A, p b p 1, p b p 2, p b p 3 \text { and } p b p 4 \text { (Argudín et al., 2016; } \\
\text { Shore et al., 2011) }\end{array}$ & \multirow{5}{*}{ High } \\
\hline Helicobacter pylori & clarithromycin-resistant & $\begin{array}{l}\text { 23srRNA (Matta et al., 2018), rpmJ, hp0605, hp0971 } \\
\text { (Iwamoto et al., 2014), acrB (Binh et al., 2014) }\end{array}$ & \\
\hline Campylobacter spp. & \multirow{2}{*}{$\begin{array}{l}\text { fluoroquinolone- } \\
\text { resistant }\end{array}$} & gyrA (Tang et al., 2017) & \\
\hline Salmonellae & & gyrA, gyrB, parC and parE (Ling et al., 2003) & \\
\hline Neisseria gonorrboeae & $\begin{array}{l}\text { cephalosporin-resistant, } \\
\text { fluoroquinolone- } \\
\text { resistant } \\
\end{array}$ & gyrA, gyrB and parC (Aldred et al., 2014) & \\
\hline Streptococcus neumonia & $\begin{array}{l}\text { penicillin-non- } \\
\text { susceptible }\end{array}$ & $\begin{array}{c}\text { Pbp2X, } p b p 2 b \text { and } p b p 1 a \text { (Chewapreecha et al., 2014; Dewé } \\
\text { et al., 2019) }\end{array}$ & \multirow{3}{*}{ Medium } \\
\hline Haemophilus influenzae & ampicillin-resistant & $\begin{array}{l}\text { Fts (Hoshino et al., 2013), TEM-1 and ROB-1 type } \beta \text { - } \\
\text { glactamase genes (Hasegawa et al., 2003) }\end{array}$ & \\
\hline Shigella spp. & $\begin{array}{l}\text { fluoroquinolone- } \\
\text { resistant }\end{array}$ & $\begin{array}{c}\mathrm{Aac}\left(6^{\prime}\right)-\mathrm{Ib}-\mathrm{cr}, \text { gyrA and gyrB (Pu et al., 2009), acr } A \text { and acrB } \\
\text { (Taneja et al., 2015) }\end{array}$ & \\
\hline
\end{tabular}


It has been seen that the drug resistance developed by microorganisms is a natural evolutionary existence and commences naturally over time. This phenomenon helps them to circulate their resistance to their progeny (Ashley \& Brindle, 1960; Beceiro et al., 2013). Furthermore, mutation at the genetic level plays a major role in many molecular mechanisms responsible for the resistance against the prescribed antibiotics (Munita \& Arias, 2016). Mutations may involve vertical evolution i.e. gene transfer from parents to offspring e.g. such as Extended-spectrum $\beta$ lactamase and plasmidic AmpC producing Escherichia coli found in poultry (Oikarainen et al., 2019); obtaining new gene i.e. horizontal gene transfers from donor to recipient by transduction, transformation and conjugation e.g. Citrobactor freundii acquires metallo- $\beta$ lactamase NDM-1 (bla NDM-1) $_{\text {) }}$ and 16S RNA methylase ArmA genes by conjugation, on the similar plasmid pNDM-CIT and possess resistance to all aminoglycosides (Dolejska et al., 2012); co-selection i.e. gene transfers due to the presence of mobile genetic elements such as plasmids, phages and transposons aids bacteria to attain variety of new traits to trigger antibiotic resistance (Jeters et al., 2009) e.g. plasmid isolated from Salmonella abortus strain that were resistant to ampicillin and transposon CTnDOT, a carrier of tetracycline resistance genes i.e. tet $Q$ and $\mathrm{erm} F$ in human colonic Bacteroides spp. (Jeters et al., 2009; Ghosh et al., 2000); compensatory mutations i.e. resistance due to dual mutation in a particular gene e.g. ribosomal mutations in $r p s L$ gene which encodes rps12 protein of the ribosomal accuracy centre is responsible for the streptomycin resistance in Escherichia coli (Levin et al., 2000); random mutations e.g. Hyper mutable (or mutator) e.g. dysregulated DNA mismatch repair system increases voluntary mutation rate up to 1000 times in Pseudomonas aeruginosa strains (Beceiro et al., 2013; Maciá et al., 2005). To date, only 13,293 genes from 933 species belongs to 124 genera are reported for 257 different antibiotics (Table-2) for treating AMR (Liu \& Pop, 2008).

Along with genetic mutations various biochemical, mechanical and physiological mechanisms are accountable for the resistance
(Munita \& Arias, 2016). Bacteria have mechanisms to inactivate/modify antibiotics, remodel the antibiotic active site to reduce its binding ability, alter its own machinery to exclude out the effects of antibiotic and reduces the effect of antibiotic by regulating the efflux pump (McManus, 1997). Almost all pathogens assemble two properties: (a) toxicity, the extremities of causing damage and (b) invasiveness i.e. tendency of expansion after the invasion. Various proteomics studies have proven that antibiotic exposure is not only lethal to bacterial cell but also triggers various stresstolerant mechanism in bacteria (Iyer \& Delcour, 1997; Nabu et al., 2017; Thorsing et al., 2013; Vega \& Delcour, 1996). Bacteria in response to antibiotics expresses a wide range of proteins required for different biological processes such as transport system, cell division, energy metabolism, stress response and virulence factor (Nabu et al., 2017).

In addition to them, the final equilibrium of an infectious disease mechanism that every microbe hold depends on the virulence or pathogenicity of the microbes and also the human community condition such as immune condition, age, diet, and stress (Beceiro et al., 2013). Nosocomial infections are also observed for the transmission of resistant bacteria. Long term exposures and wide usage of antibiotics also deplete the immune system and make patients more susceptible to mild diseases and eventually leading to the failure of antibiotics to treat the infection (Rakoff-Nahoum et al., 2004). These factors in unification with genetic factors are also accountable for the rising and expansion of antimicrobial resistance. It is not all about the human community but we can also consider animals. Animal husbandry is the foundation of exploiting antibiotics and averting diseases (Chuma et al., 2013; Antimicrobial resistance, 2018). The transfer of erm $A$ and $\operatorname{erm} C$ resistant genes through transposition and transformation respectively, from poultry to human clinical Staphylococcus aureus strain is a better example of transfer to the resistance between same pathogenic isolate belongs to different ecological niche (Khan et al., 1999). 
Table 2. The summary of the method of action for the main classes is given in table (Hart \& Kariuki, 1998).

\begin{tabular}{|c|c|c|c|}
\hline Antibiotic Class & Antibiotics name & Role of antibiotic & Mode of antibiotic action \\
\hline B-lactam & $\begin{array}{c}\text { Penicillins } \\
\text { Cephalosporins } \\
\text { Carbanepems } \\
\text { Glycopeptides } \\
\text { Fosfomycins }\end{array}$ & Bactericidal & Inhibit cell wall synthesis \\
\hline Lipopeptides & $\begin{array}{l}\text { Polymixins A } \\
\text { Polymixins B } \\
\text { Polymixins C } \\
\text { Polymixins D } \\
\text { Polymixins E }\end{array}$ & Bactericidal & Inhibit membrane function \\
\hline $\begin{array}{c}\text { Quinolones } \\
\text { Furanes }\end{array}$ & $\begin{array}{c}\text { Ofloxacin } \\
\text { Ciprofloxacin } \\
\text { Norfloxacin } \\
\text { Nitrofurantoin } \\
\text { Metronidazole } \\
\text { Rifamycins }\end{array}$ & Bactericidal & $\begin{array}{l}\text { Inhibits DNA synthesis } \\
\text { Inhibit RNA transcription }\end{array}$ \\
\hline Aminoglycosides & $\begin{array}{l}\text { Gentamicin } \\
\text { Tobramycin } \\
\text { Amikacin }\end{array}$ & Bactericidal & \multirow{5}{*}{ Inhibit protein synthesis } \\
\hline $\begin{array}{l}\text { MLSK (macrolides, } \\
\text { lincosamides, } \\
\text { streptogramins, } \\
\text { ketolides) } \\
\end{array}$ & Erythromycin & & \\
\hline Ansamycins & $\begin{array}{l}\text { Rifampin } \\
\text { Clindamycin } \\
\text { Clarithromycin } \\
\text { Azithromycin }\end{array}$ & Bacteriostatic & \\
\hline Tetracyclines & Tetracycline & & \\
\hline $\begin{array}{c}\text { Phenocols } \\
\text { Oxazolidones }\end{array}$ & $\begin{array}{c}\text { Chloramphenicol } \\
\text { Linezolid }\end{array}$ & & \\
\hline
\end{tabular}

This article recapitulates a brief overview on the alternatives used by bacteria to overcome antibiotic action and the severity of antibiotic resistance at the global scale. We mainly focus on the various paradigm from the literature and suggest that there is a need to educate people to develop various alternatives to overcome future challenges of antibiotic resistance.

\section{Mechanistic action of resistance against antibiotics}

The microorganisms in pursuit of having antimicrobial resistance are evolved either by intrinsic, adaptive or acquired resistance mechanisms (Figure 1). Intrinsic resistance is due to the inherent insensitivity in the microorganism that is insusceptible to antimicrobials. In intrinsic resistance, antimicrobial agents fails to cross pathogen's outer membrane due to which bacteria is able to survive in the presence of antibiotic stress (Munita \& Arias, 2016). It is a universal trait of any bacteria which lies within the strain and is totally independent of gene transfer (Martinez \& Baquero, 2000; Palmer et al., 2010). MDR is a better conventional example of intrinsic resistance (Masi \& Pagès, 2013). Bacteria can acquire resistance either through new genetic incorporation or getting external DNA from nearby species that is already resistant e.g. acquired vancomycin resistance VanG-type in 
Enterococcus faecalis BM4518 (Tenover, 2006). Enterococcus faecalis BM4518 induces resistance due to the synthesis of peptidoglycan precursor ending in D-alanyl-D-serine (Weber et al., 2009). Later on a transferable VanN-type resistance is reported in Enterococcus faecium (Hegstad et al., 2010; Lebreton et al., 2011). The basis of acquired resistance can describe by mean of horizontal or vertical gene transfer.

Microorganisms encounter with multitude of environmental factors during their evolutionary period which includes ecological niche, annual temperatures, seasonal variations, day-night cycles and nutrient burden. These changes are not instant but occur over a manifold timescale. Accordingly, microbes have evolved varied approaches to deal with extreme ecological niche, environmental variation and physiological adjustments. To survive microbes, maintain their cellular integrity by repairing and utilizing environmental resources during physical changes. Such type of physical responses against the cruelty of the environment is a natural selection procedure and occurs due to evolution (Galhardo et al., 2007; Hochachka et al., n.d.; Huisman \& Kolter, 1994; Kennedy et al., 2001; Kushner, 1978; Mitchell et al., 2009; Ouyang et al., 1998; Ram et al., 2005; Woelfle et al., 2004). Exposure to nonlethal antimicrobial doses, ion concentration and temperature are some other environmental factors which enhance their attribute of resistance (Fernández \& Hancock, 2012).

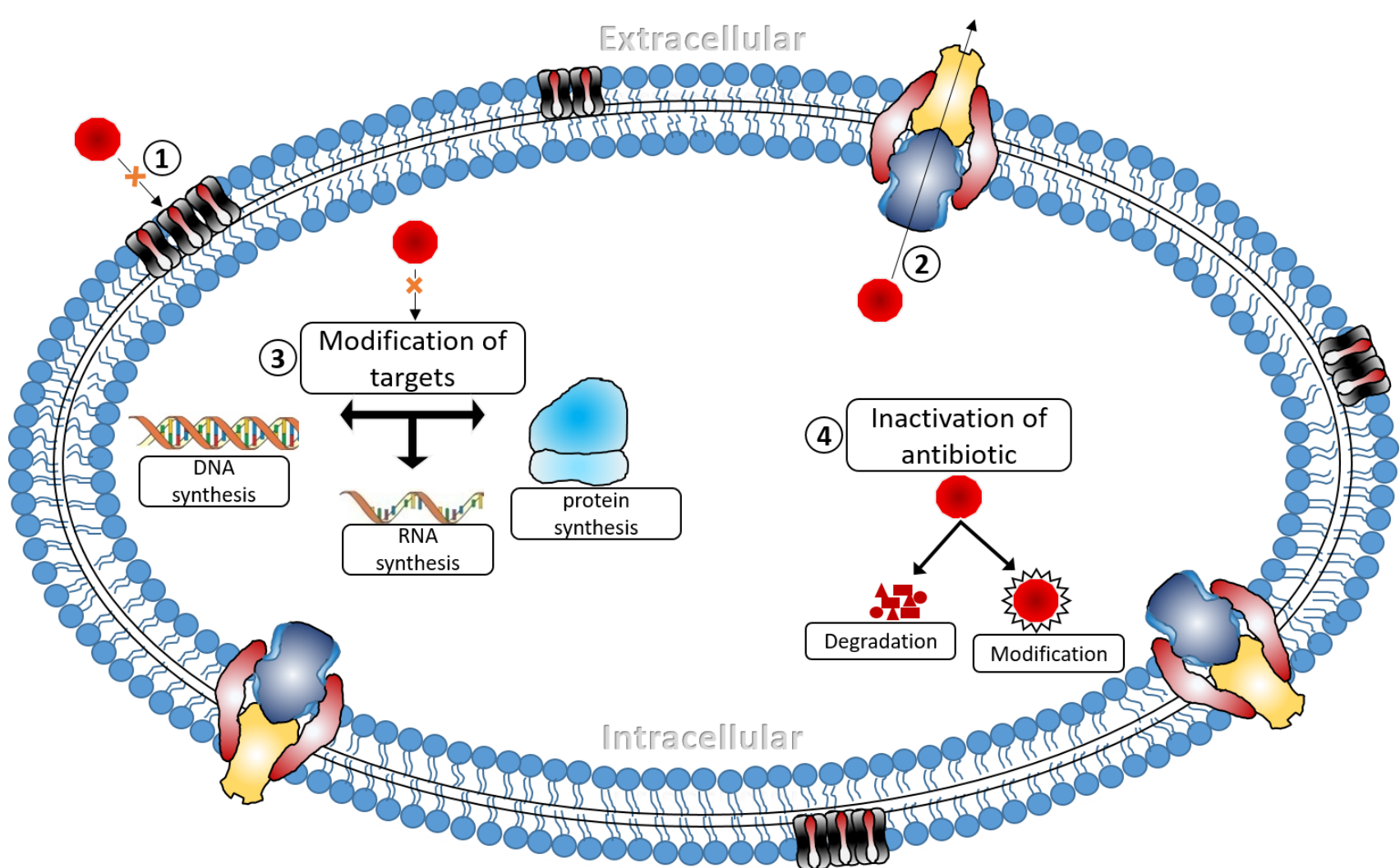

Figure 1. Mechanisms responsible for antibiotic resistance in bacteria includes antibiotic alteration antibiotics; Ribosomal alteration; altered efflux pump; Porins alteration (first line of defense in bacteria that blocks antibiotic entry in host cell). In the given figure legends are depicting as follow (1) Several mutations in the coding genes of porins and their down regulation leads to its alteration that block antibiotic entry, (2) Efflux pump, active transporter and are responsible for the removal of toxic substances out of the cell. Hence alteration in efflux pump due to continuous exposure to antibiotic leads to antibiotic resistance, (3) Ribosomal alteration leads to target site alteration which in response inhibit antibiotic binding to target site, (4) Antibiotic inactivation either by its modification or degradation respectively by host enzymes. 


\section{Prevention of antibiotic access across the bacterial cell}

\section{Loss of porins}

Bacteria have an inbuilt mechanism for uptake of hydrophilic compounds of a specific size (Danilchanka et al., 2008). These compounds travel through water-filled channels known as porins present on the outer membrane of their cell wall (Silhavy et al., 2010). For the first time in 1976, these proteins were identified in Escherichia coli strain (Nakae, 1976). Porins lacking a classic hydrophobic region and allow less hydrophilic antibiotic uptake inside the cell (Kojima \& Nikaido, 2013; Lambert, 2002; Lambert, 2005; Vargiu \& Nikaido, 2012). Hence downregulation or replacement of porins is associated with certain types of antibiotic resistance. These dysregulated porins reduce membrane permeability and hence restricting antibiotic entry inside the bacterial cell (Tamber \& Hancock, 2003) (Table 3).

Table 3. There are different types of porins channels present in each bacterial species. Some of them responsible for antibiotic resistance are listed in the table (Fernández \& Hancock, 2012).

\begin{tabular}{cc}
\hline Bacterial species & $\begin{array}{c}\text { Porins responsible } \\
\text { for antibiotic } \\
\text { resistance }\end{array}$ \\
\hline Psendomonas aeruginosa & OprD \\
Escherichia coli & OmpC, OmpF \\
Serratiamarcescens & OmpF, OmpC \\
Klebsiellapneumoniae & OmpK35, OmpK36 \\
Enterobacter cloacae & OmpF \\
Enterobacteraerogenes & OmpC, OmpF \\
Klebsiellaoxytoca & Omp36 \\
Neisseriagonorrboeae & OmpK36 \\
Salmonella enteric & $\mathrm{PIB}$ \\
Vibrio cholera & $\mathrm{OmpC}, \mathrm{OmpF}$ \\
Acinetobacterbaumannii & $\mathrm{OmpU}$ \\
\hline
\end{tabular}

Loss of outer membrane protein (porins) expression has been proposed as an important mechanism of carbapenem resistance. Mutation in coding sequences and overexpression of bacterial small RNA (sRNAs), down-regulate the porins expression in carbapenem-resistant isolate Enterobacter aerogenes (Hao et al., 2018). Porins are beta proteins and are of different types (Table 4) in which general porins are highly subjected to antibacterial vulnerability and resistance. These are non-selective channels and allow preferences for positively or negatively charged molecules.

In the case of Escherichia coli certain general porins such as $\mathrm{OmpF}$ and $\mathrm{PhoE}$ act as a gateway for the diffusion of hydrophilic molecules (Achouak et al., 2001; Fernández \& Hancock, 2012). In some cases the regular dosage of antibiotic pressure initiate certain mutational changes on transcription factor leading to the loss of porins expression as indicated by the development of carbapenem resistance in Escherichia coli trans conjugant (Kong et al., 2018). Carbapenem belongs to a class of $\beta$-lactam antibiotics which is also effective against disease caused by Pseudomonas aeruginosa (Hong et al., 2015). However, carbapenem-resistant Pseudomonas isolates are constantly reported worldwide due to loss of substrate-specific outer membrane porin protein OprD (Hancock \& Brinkman, 2002; Trias \& Nikaido, 1990). Serratia marcescens is a Gram-negative bacteria and reported for the $\beta$-lactam resistance due to reduction in outer membrane porins protein (Grimont \& Grimont, 1984; Sanders \& Sanders $\mathrm{Jr}, 1992)$. Serratia marcescens exhibit $\mathrm{OmpF}$ and OmpC porins regulation in response to environmental stress conditions such as osmotic pressure, temperature and $\mathrm{pH}$ variability. Both of the porins protein is highly regulated by RNA transcript micF which inhibit porins translation under these environment stress (Begic \& Worobec, 2006). In addition, micF is also reported to reduce the expression of ompK35 (ompF) in ceftazidime resistance in Klebsiella pneumonia (Shen et al., 2017). Acquisition of Klebsiella pneumonia, a major cause of nosocomial infection become a major problem due to its resistance against a number of $\beta$-lactam antibiotics due to loss or modifications of OmpK35 and OmpK36 porins proteins (GarcíaFernández et al., 2012). In the late 1970s and early 1980s Neisseria gonorrboeae become more resistant to penicillin and tetracycline. Studies have shown porin protein PIB, encoded by pen $B$ gene is responsible for the gradual increase in resistance (Gill et al., 1998; Olesky et al., 2002). Mutations in the amino acids sequence of $p e n B$ at position 120 and 121 in association with mutation in $m t r R$ were preferred for the increased resistance to penicillin and tetracycline (Olesky et al., 2006) 
Table 4. There are some different classes of porins and their function are given in the table (Fernández \& Hancock, 2012).

\begin{tabular}{cc}
$\begin{array}{c}\text { Classes of } \\
\text { porins }\end{array}$ & Function \\
\hline General porins & $\begin{array}{c}\text { Determining the permeability } \\
\text { barrier }\end{array}$ \\
\hline $\begin{array}{c}\text { More specific } \\
\text { porins }\end{array}$ & $\begin{array}{c}\text { Involve in the uptake of specific } \\
\text { substrates (e.g., LamB, which is } \\
\text { involved in the uptake of } \\
\text { maltose and maltodextrins) }\end{array}$ \\
\hline $\begin{array}{c}\text { Energize cytoplasmic membrane } \\
\text { system to enable the specific } \\
\text { membrane } \\
\text { proteins } \\
\text { (OMPs) }\end{array}$ & $\begin{array}{c}\text { uptake of relatively rare iron } \\
\text { complexes with secreted } \\
\text { bacterial siderophores (e.g., the } \\
\text { ferric enterochelin channel } \\
\text { FepA) }\end{array}$ \\
\hline
\end{tabular}

\section{Dysregulated efflux pump}

Bacteria also consist of energy derived channels to eject toxic compound out of the cell (Table-5). This mechanism helps bacteria to pump out antibiotic out of the cell efficiently instead of altering it. Reduction in tetracycline aggregation in Escherichia coli was identified in 1978 by Levy and McMurry (Levy \& McMurry, 1978). Later studies have proven the role of an efflux pump that have intrinsic resistance in Pseudomonas (Galhardo et al., 2007; Kennedy et al., 2001; Kushner, 1978).

Furthermore, altered membrane permeability as a result of porins alterations and efflux pump over expression stays constantly associated with multidrug resistance (MDR) (Masi \& Pagès, 2013). Most multi-resistance systems are chromosomally encoded. Active multidrug efflux pump supports intrinsic resistance of a bacterial pathogen. Efflux pump has a self-regulatory gene to control expression (Thanassi et al., 1997). For instance, overexpression of several genes such as $m d f A, \operatorname{mar} A, y b i U$ and $y b i V$ in Escherichia coli are reported to exhibit resistance against fluoroquinolones (Bohnert et al., 2007; Keeney et al., 2008). Hence, mutational changes in repressor genes increased expression that leads to resistance (Levy \& McMurry, 1978) or may result from global transcriptional regulator activation (Ball et al., 1980; Pomposiello \& Demple, 2000). Several time bacteria harness these mutations coherently for antibiotic exclusion and resistance emergence (Fernández \& Hancock, 2012). In particular, many bacteria possess intrinsic resistance to many antibacterial agents due to the presence of multidrug efflux transporters system (Nikaido, 1994). The emergence and spread of multidrugresistant Pseudomonas aeruginosa have been recognized as perturbing species in the health care industry as very few agents are effective against these strains (Fischbach \& Walsh, 2009; Poole, 2011). Up regulation of MexXY pump is the reported mechanism of aminoglycoside resistance in cystic fibrosis lung isolates Pseudomonas aeruginosa (Armstrong \& Miller, 2010; Poole, 2011).

Among all the given efflux pumps (Table-5), the over expression of RND (resistancenodulation-division) family of MDR system has proven for the removal of extremely broad categories of clinical substances (Blair et al., 2015). In which MexXY pump was found for the first time in Pseudomonas aeruginosa PAO1 strain (Mine et al., 1999). Another study on Pseudomonas aeruginosa PA154197 strain revealed the over expression of several MDR efflux pump such as MexAB-OprM, MexEF-OprN and MexGHIOpmD. Major virulence factor in Pseudomonas aeruginosa PA154197 strain is controlled by a secondary quorum-sensing system which involved in antibiotic resistance (Cao et al., 2019). Further studies have revealed that there are additional MDR efflux pumps like MdeA in Streptococcus mutans, FuaABC in Streptococcus maltophilia, KexD in Klebsiella pneumoniae and LmrS in Staphylococcus aureus (Floyd et al., 2010; Hu et al., 2012; Kim et al., 2013; Ogawa et al., 2012). HasF, one of the efflux system of RND efflux super family linked with MDR has found in Serratia marcescens strain against KAM32 (Toba et al., 2019).

\section{Mutational modification of antibiotic target site}

Microbes acquire resistance either by inheriting new genetic components or mutations in the existing gene. In such events, the genetic transmission is held either by conjugation, transduction, or transformation (Lambert, 2005). The alteration due to transmission in target structure, reduces the antibiotic binding affinity but does not affect the microbes itself to carry their normal function. For example, resistance in Streptococcus pneumonia strain due to mutation in penicillin-binding protein gene $(p b p)$ such as $(1 A$, $1 B, 2 A, 2 X$ and $2 B$ ) encodes for the penicillin- 
insensitive enzyme (Unemo et al., 2012). Hence, alteration events in these high molecular weight PBPs have led to low affinity for antibiotics. Results were validated by protein electrophoresis assay using radio labelled penicillin (Hakenbeck et al., 1980; Zighelboim \& Tomasz, 1980). More recently, it has been identified that this modified trait of PBPs has arisen due to interspecies recombination by transformation and localized recombination between homologous genes at least from two unidentified closely related species (DowsON et al., 1990) that results in mosaic gene PBP2B formation (Unemo et al., 2012).

Moreover, bacteria smartly acquire similar gene as that of the target protein and render its own mechanism to resist the target protein effect. In the case of methicillin resistance, Staphylococcus aureus attains Staphylococcal cassette chromosome mec (SCCmec) element encoding for PBP2 protein, has led its emergence (Katayama et al., 2000; McManus, 1997). By attaining this trait MRSA is able to form specific penicillin-binding protein PBP $2 a$ and hence reduces binding affinity to $\beta$ lactam antibiotics (Brown \& Reynolds, 1980; Hartman \& Tomasz, 1984; Utsui \& Yokota, 1985). These MRSA strains encoding PBP $2 a$ proteins are basically originated from hospitals in all over the world (Ito et al., 1999; Ito et al., 2001; Kuroda et al., 2001).

Other than gene mutation bacteria utilize other mechanisms for their survival. One of the examples is an erythromycin ribosome methylase (erm) family of genes in bacteria (Khan et al., 1999). Bacteria utilize these genes to methylate $16 \mathrm{~s}$ rRNA ribosomal subunit to reorient active drug binding sites. Thereby, averts the binding of some class of antibiotics such as macrolides, lincosamines and streptogramins (Long et al., 2006). Recently a study has reported the association of erm gene in reduced solithromycin susceptibility against Staphylococcus aureus strain (Yao et al., 2019). Interestingly, the characterization of chloramphenicol-florfenicol resistance (cfr) methyltransferase unveils that methylation of A2503 gene in $23 \mathrm{~S}$ rRNA results in resistance against the majority of drugs such as phenicols, pleuromutilins, streptogramins, lincosamide and oxazolidonones (including linezolid) (Long et al., 2006). Both the genes erm and cfr are transmitted together on plasmid for the distribution among bacteria (Leclercq, 2002; Zhang et al., 2013).
Molecular distribution and resistance mechanism in Campylobacter coli reveal the presence of a broad array of resistance mechanisms against a number of antibiotics such as ciprofloxacin, nalidixic acid, tetracycline and erythromycin. Antibiotic ciprofloxacin and nalidixic isolates express gyrA T861 substitution, tet $(\mathrm{O})$ gene among tetracycline-resistant isolates and 23rRNA A2075G mutation among erythromycin-resistant isolates (Elhadidy et al., 2019). The high mutation rate in gyrA among Uropathogenic isolates Escherichia coli is also associated with quinolone resistance (Shenagari et al., 2018). Another class of antibiotic fluoroquinolones resistance is also associated with a mutation in DNA gyrase or topoisomerase IV genes in Mycoplasma hominis strain (Zhang et al., 2019).

\section{Modification of antibiotics}

Further studies on the antibiotic resistance have revealed various examples of antibiotic alteration which is done by enzyme-catalyzed reactions that hydrolyses the antibiotics (Abraham \& Chain, 1940). For the fulfillment of survival, microbes expresses several class of $\beta$-lactamases enzymes such as penicillinase (hydrolyzes penicillin and early generation cephalosporin), extendedspectrum $\beta$-lactamases (ESBL) (hydrolyzes late generation cephalosporin), Class-A carbapenemases (hydrolyzes penicillins, cephalosporins and carbapenem), cephalosporinases (hydrolyzes cephalosporin), oxacillinase (hydrolyzes cloxacillin or oxacillin) and metallo- $\beta$-lactamases (hydrolyzes broad spectrum of $\beta$-lactam ring of antibiotic such as penicillins, cephalosporins, monobactams, carbapenems and cephamycins etc.) (Chuma et al., 2013; Jacoby \& Munoz-Price, 2005). Hydrolysis of $\beta$-lactam antibiotics is the most common resistance mechanism reported in Gram-negative bacteria. There are mainly four known mechanisms of $\beta$-lactam antibiotic resistance; hydrolysis of the $\beta$-lactam ring by $\beta$-lactamase; production of PBPs to maintain bacterial cell wall; porins channels modification; efflux protein initiation (Fisher et al., 2005; Massova \& Mobashery, 1998). PBPs and $\beta$-lactam antibiotics cluster together and possess a public health threat that causes $\beta$-lactam antibiotic resistance (Massova \& Mobashery, 1998). These enzymes also modify antibiotics by adding several chemical 
groups on their active site. Hence avert antibiotic binding due to steric hindrance. So far it can be said that these traits enhance pathogen's ability and widespread their resistance at a larger scale (Wright, 2005). Enzymatic modification of aminoglycoside is also another example of the emergence of resistance. Aminoglycoside acts synergistically in combination either with vancomycin or $\beta$-lactam (Fatholahzadeh et al., 2009). Several classes of aminoglycosides structure modifying enzyme such as aminoglycoside phosphotransferase, acetyltransferase and nucleotidyltransferase (Seyedi-Marghaki et al., 2019).

Table 5. Different bacterial efflux transporters are classified into five major super families based on their amino acid sequence and the energy source used to export their substrates, given in table 5 (Ayaz, 2017; Tseng et al., 1999).

The major facilitator superfamily (MFS)

The small multidrug resistance family (SMR)
Secondary active transporter
The Sugar Porter (SP) Family

The Drug: H+ Antiporter-1 (12 Spanner) (DHA1) Family

The Drug: H+ Antiporter-2 (14 Spanner) DHA2) Family

The Organophosphate: Pi Antiporter (OPA) Family

The Oligosaccharide: $\mathrm{H}+$ Symporter (OHS) Family

The Metabolite: $\mathrm{H}+$ Symporter

(MHS) Family fructose-glucosegalactose $\mathrm{H}+$ symporter (FGHS)Family

The Nitrate/Nitrite Porter (NNP) Family

The Phosphate: H+ Symporter (PHS) Family

The Nucleoside: H+ Symporter (NHS) Family

The Oxalate: Formate Antiporter (OFA) Family

The Sialate: H+ Symporter (SHS) Family

The Monocarboxylate Porter (MCP) Family

The Anion: Cation Symporter (ACS) Family

The Aromatic Acid: $\mathrm{H}+$ Symporter (AAHS) Family

"unknown major facilitator superfamily" (UMFS) Family

The Cyanate Permease (CP) Family

The Proton-dependent Oligopeptide Transporter (POT) Family

The small multidrug pumps (SMP) Suppressor of groEL mutation proteins (SUG), and a third group Paired small multidrug resistance proteins (PSMR).
XylE transporter of Escherichia coli

QacA of Staphylococcus aureus

Bmr transporter of Bacillus subtilis

UhpT transporter of Escherichia coli

LacY transporter, Kgt transporter,

FucP transporter and

NarK transporter of Escherichia coli

Pho-5 transporter of Neurospora crassa

NupG transporter of Escherichia coli

OxlT transporter of

Oxalobacter formigenes Nan'T and

ExtU transporter of Escherichia coli

PcaKo transporter of Pseudomonas putida 


\begin{tabular}{|c|c|c|c|}
\hline $\begin{array}{c}\text { The resistance } \\
\text { nodulation-cell } \\
\text { division superfamily } \\
\text { (RND) }\end{array}$ & & $\begin{array}{c}\text { The heavy metal efflux (HME) } \\
\text { The hydrophobe/amphiphile efflux-1 } \\
\text { (gram-negative bacteria) } \\
\text { The nodulation factor exporter family } \\
\text { (NFE) } \\
\text { The SecDF protein-secretion } \\
\text { accessory protein family } \\
\text { The hydrophobe/amphiphile efflux-2 } \\
\text { family } \\
\text { The eukaryotic sterol homeostasis } \\
\text { family } \\
\text { And the hydrophobe/amphiphile } \\
\text { efflux-3 family. }\end{array}$ & $\begin{array}{c}\text { MexB of Pseudomonas } \\
\text { aeroginosa } \\
\text { AcrB of Escherichia coli } \\
\text { MexAB-OprM, } \\
\text { MexEF-OprN, } \\
\text { MexXY, } \\
\text { MexJK and } \\
\text { MexEF-OpmD of } \\
\text { Pseudomonas aeruginosa }\end{array}$ \\
\hline $\begin{array}{l}\text { The Multi } \\
\text { antimicrobial } \\
\text { extrusion } \\
\text { protein family } \\
\text { (MATE) }\end{array}$ & & $\begin{array}{c}\text { MATE transporter proteins like } \\
\text { NorM in V. parahaemolyticus, a } \\
\text { prototype transporter } \\
\text { Eukaryotic MATE proteins } \\
\text { Subfamily - } \\
\text { 2A represents fungal and yeast } \\
\text { MATES } \\
\text { 2B represents plant MATES } \\
\text { 2C comprises animal MATES and 2D } \\
\text { consists of protozoal MATES } \\
\text { Bacterial and archaeal MATES }\end{array}$ & $\begin{array}{c}\text { NorM of Vibrio } \\
\text { parabaemolyticus } \\
\text { PmpM of Pseudomonas } \\
\text { aeruginosa } \\
\text { HmrM of Haemophilus } \\
\text { Influenza } \\
\text { YdhE of Escherichia coli } \\
\text { NorM of Brucella } \\
\text { melitensis } \\
\text { MepA of Staphylococcus } \\
\text { Aureus } \\
\text { AbeM of Acinetobacter } \\
\text { baumannii } \\
\text { CdeA of Clostridium } \\
\text { difficile } \\
\text { VcmA, VcrM, etc of } \\
\text { Vibrio cholerae } \\
\text { BexA of Bacteroides } \\
\text { thetaiotaomicron } \\
\text { Erc1 of Saccharomyces } \\
\text { cerevisiae } \\
\text { NorM of Erwinia } \\
\text { amylovora }\end{array}$ \\
\hline $\begin{array}{c}\text { The ATP-binding } \\
\text { cassette superfamily } \\
\text { (ABC) }\end{array}$ & $\begin{array}{l}\text { Primary active } \\
\text { transporters }\end{array}$ & $\begin{array}{l}\begin{array}{l}\text { ATP binding cassette subfamily A } \\
\text { (ABCA) } \\
\text { ATP binding cassette subfamily B } \\
\text { (ABCB) } \\
\text { ATP binding cassette subfamily C } \\
\text { (ABCC) } \\
\text { ATP binding cassette subfamily D } \\
\text { (ABCD) } \\
\text { ATP binding cassette subfamily E } \\
\text { (ABCE) } \\
\text { ATP binding cassette subfamily F } \\
\text { (ABCF) } \\
\text { ATP binding cassette subfamily G } \\
\text { (ABCG) } \\
\text { ATP binding cassette subfamily H } \\
\text { (ABCH) }\end{array}\end{array}$ & $\begin{array}{c}\text { Ard1 of Streptomyces } \\
\text { capreolus } \\
\text { TnrB of Streptomyces } \\
\text { longisporoflavus } \\
\text { LmrA of Lactococcus } \\
\text { lactis }\end{array}$ \\
\hline
\end{tabular}




\section{Approaches to enhance the antibacterial activity}

Bioprospecting of natural products that have useful pharmacological compounds are in trends nowadays. Majority of antibiotic resistance against routinely utilized antibiotics has to lead the exploitation of natural sources such as plants, microorganisms and fungi (Simoes et al., 2009). Due to antibacterial activities, these naturally derived phytochemicals can restore the potency of older antibiotics as a consequent and can be served as an alternative approach to treat resistance (Savoia, 2012).

Although the number of phytochemicals are present in natural resources, only few have been identified (Cao et al., 2017; Singh \& Chaudhuri, 2018). The most common phytoconstituents are anthraquinones, carotenoids, catechins, flavonoids, ginsenosides, indoles, lignans, polyphenol, phenolic acids, phenylpropanoids, saponins etc. (Xiao, 2017; C. Zhao et al., 2017). Various classes of alkaloids have been investigated for their antibacterial mechanism of action. It has been proposed that indolizidine class of alkaloids inhibit nucleic acid synthesis by inhibiting dihydrofolate reductase enzyme (Rao \& Venkatachalam, 2000). Moreover, polyamide alkaloid compromises outer and cytoplasmic membrane integrity and can cause leakage of cytoplasmic content (Alhanout et al., 2010; Salmi et al., 2008). Berberine, an isoquinoline alkaloid isolated from roots and stem-bark of Berberies plant species is known to inhibit nucleic acids synthesis of various pathogens such as bacteria, fungi and protozoa (Domadia et al., 2008; Yi et al., 2007). Besides their antibacterial activity these phytochemicals in combination with conventional antibiotics may possess a different mode of action through different target sites of bacteria and hence can be utilized as an additional therapy to improve conventionally available antibiotics. For example, the antibacterial activity of sulfurcontaining phytochemicals such as allicin, dialkenyl, S-allele-cysteine, dialkyl sulphides and isothiocynates from plants against both Grampositive and Gram-negative bacteria (Barbieri et al., 2017; Sobolewska et al., 2015). An organosulfur compound Allicin (diallyl thiosulfinate) obtained from garlic has been studied for its antibacterial activity against a variety of bacteria such as Staphylococcus epidermidis,
Pseudomonas aeruginosa and MRSA (Reiter et al., 2017). The antibacterial mechanism of action of allicin has been reported to inhibit sulfhydryldependent enzymes such as alcohol dehydrogenase and RNA polymerase (Lanzotti et al., 2014). Further allicin is also reported to target RNA synthesis in the host organism (Feldberg et al., 1988). Resveratrol, a phenolic compound is known to inhibit efflux pump Cme $A B C$ of Campylobacter jejuni and Mycobacteriaum smegmatis (Klančnik et al., 2017; Lechner et al., 2008). Moreover, phenolic compound biochanin A is able to reduce the expression of NorA efflux pump of MRSA (Zou et al., 2014). Nonetheless, curcumin a well-known phenolic compound obtained from Turmeric plant shows antibacterial activity against Staphylococcus aureus and Escherichia coli by disrupting their cell membrane (Tyagi et al., 2015).

Bacterial infection leading to animal death are also a major concerns associated with economic loses. Hence there is a critical need of a potential alternative to antibiotics which can further elevate its present ability. In this regards a study in which nisin in combination with essential oil from herbal plants brought evidence of potential inhibitor against respiratory tract pathogen Streptococcus suis (LeBel et al., 2019). Nonetheless essential oils isolated from Santalum spp. and Vetiveria zinzanioides plants alone and in combination showed considerable antimicrobial activity and presented as a feasible approach in wound healing therapy (Orchard et al., 2018). Respiratory tract infections and cancer-related deaths are dominating all over the world and hence there is a demand of effective chemotherapy compounds with reduced side effects is needed. Phytochemical tanshinones, abietane diterpenes extracted from Salvia miltiorrbiza exhibits versatile anticancer activity against doxorubicin resistant gastric cancer cells (Xu et al., 2018). According to the WHO fact sheet 2018, resistance to malaria become a major public health concern nowadays and the majority of the strains are getting resistant to the number of anti-malarial medicines. Plant extract from Zingiber officinale and Echinops kebericho mesfin is reported for exhibiting anti-plasmodial activity suggesting its usage in treating malaria (Biruksew et al., 2018). Phyllanthin compound extracted from Phyllanthus amarus plant is able to modulate fluoroquinolone-resistance by 
inhibiting NorA efflux pump in Staphylococcu aureus SA1199-B strain and could be a potential agent to treat infection (Ribeiro et al., 2019). A number of studies also reporting the antimicrobial activities of the number of extracts, essential oils, resins and various compounds derived from herbal plants in recent years (Kokoska et al., 2019).

Recently characterization of vaginal microbiota Lactobacillus strain is studied for lactic acid and bacteriocin production (Fuochi et al., 2017). These substances are not only with antibacterial activity but can be utilized as a cotherapy in combination with antibiotics prescribed (Fuochi et al., 2019; Tachedjian et al., 2017). Modern techniques indeed led our knowledge to stimulate developments of alternative therapies. Bioengineered lysinbacteriocin amalgamated molecule termed as lysocins does not only disrupt peptidoglycan in Pseudomonas aeruginosa but also degrade biofilm efficiently. This modern approach can be a suitable module to target other pathogenic Grampositive strains (Heselpoth et al., 2019). Nonetheless usage of probiotics also has proven effective against several Gram-negative strain (Öncül \& Yildırım, 2019). Moreover, the pathogenicity of Mycobacterium paratuberculosis has the account to dairy animals as well as a human being (Naser et al., 2014). Therefore, nisin treatment could be an improving approach not only by decreeing Mycobacterium paratuberculosis cell number in milk products but also in animals too (Ali et al., 2019). Recently characterized BaCf3 bacteriocin isolated form Bacillus amyloliquefaciens strain has been proved as a probable biofilm and growth inhibitor against certain food borne pathogens (Bindiya et al., 2019).

In addition to this utilization of nanoparticles is in trend nowadays (Nejabatdoust et al., 2019). Tobramycin conjugated to $\mathrm{Fe}_{3} \mathrm{O}_{4}$ (iron oxide) nanoparticles was investigated against Pseudomonas aeruginosa in cystic fibrosis diseases (Brandt et al., 2013). Therefore, nanoparticles such as zinc oxide, iron oxide and silver can be a novel approach to treat pathogenic infection due to their broad-spectrum antimicrobial activity (Alam et al., 2019; Nejabatdoust et al., 2019; Rafińska et al., 2019). Nonetheless, several D-amino acids are also cited as a therapeutic agent against several Uropathogenic bacteria (Korte-Berwanger et al., 2013).

\section{CONCLUSION}

The emergence of antibiotic has revolutionized the treatment of major infectious diseases and from there on numerous mechanisms have been learnt up to develop several novel antibiotics. However, the early era of antibiotic generations has successfully treated the infectious diseases but with the passage of time continuous exposure of antibiotic has led them to develop alternative pathways alterations/modification at the cellular level to survive against various classes of antibiotics, which indeed have challenged the health of people all around the world. For that pursuance more studies on the mechanism (physiological, metabolic and genetic) pertaining to their adaptations are required to develop novel antibiotics.

Microbes obtain resistance against antibiotics is entirely hinge on the method of action of antibiotics. This include membrane permeability, active efflux pump lead to MDR, modification in target site, inactivation of antibiotic via enzyme production or additional intermediary materials then finally alterations within genetic material which entirely impact in resistance production. Hence, there is a necessity of novel antibiotic along with novel microbe's extermination mechanisms or else through a modified mechanism. Some additional approaches like the addition of stable products, using antibiotics in combination or by modifying their characteristics which in turn enhance antibiotic capability. These new approaches can be helpful in inactivating bacterial protein synthesis destruct their DNA synthesis and inhibit their self-defense mechanism. In fact, some researchers are using antibodies, herbal plants extract and probiotics to enhance antibiotic capability. However, there is a need for in-depth studies to ensure the mechanism of action and safety of antibacterial phytochemicals.

\section{REFERENCES}

Abraham, E. P., \& Chain, E. 1940. An enzyme from bacteria able to destroy penicillin. Nature 146(3713): 837.

"About Antimicrobial Resistance-Antimicrobial/Antimicrobial Resistance-CDC”. www.cdc.gov. 19 September 2017. 
Archived from the Original on 1 October 2017. Retrieved 8 September 2017.

Achouak, W., Heulin, T., \& Pagès, J.-M. 2001. Multiple facets of bacterial porins. FEMS Microbiology Letters 199(1): 1-7.

Akova, M. 2016. Epidemiology of antimicrobial resistance in bloodstream infections. Virulence 7(3): 252-266.

Alam, T., Khan, R. A. A., Ali, A., Sher, H., Ullah, Z., \& Ali, M. 2019. Biogenic synthesis of iron oxide nanoparticles via Skimmia laureola and their antibacterial efficacy against bacterial wilt pathogen Ralstonia solanacearum. Materials Science and Engineering: C 98: 101-108.

Aldred, K. J., Kerns, R. J., \& Osheroff, N. 2014. Mechanism of quinolone action and resistance. Biochemistry 53(10): 15651574.

Alhanout, K., Malesinki, S., Vidal, N., Peyrot, V., Rolain, J. M., \& Brunel, J. M. 2010. New insights into the antibacterial mechanism of action of squalamine. Journal of Antimicrobial Chemotherapy 65(8): 1688-1693.

Ali, Z. I., Saudi, A. M., Albrecht, R., \& Talaat, A. M. 2019. The inhibitory effect of nisin on Mycobacterium avium ssp. paratuberculosis and its effect on mycobacterial cell wall. Journal of Dairy Science 102(6): 4935-4944.

Alvarez-Ortega, C., Wiegand, I., Olivares, J., Hancock, R. E., \& Martínez, J. L. 2011. The intrinsic resistome of Pseudomonas aeruginosa to $\beta$-lactams. Virulence 2(2): 144 146.

Antimicrobial resistance. World Health Organization. http://www.who.int/news-room/fact-sheets/detail/anti microbial-resistance. Cited 27 October 2018.

Argudín, M. A., Dodemont, M., Taguemount, M., Roisin, S., De Mendonça, R., Deplano, A., Nonhoff, C., \& Denis, O. 2016. In vitro activity of ceftaroline against clinical Staphylococcus aureus isolates collected during a national survey conducted in Belgian hospitals. Journal of Antimicrobial Chemotherapy 72(1): 56-59.

Armstrong, E. S., \& Miller, G. H. 2010. Combating evolution with intelligent design: The neoglycoside ACHN-490. Current Opinion in Microbiology 13(5): 565-573.

Ashley, D. J., \& Brindle, M. J. 1960. Penicillin resistance in staphylococci isolated in a casualty department. Journal of Clinical Pathology 13(4): 336-338.

Ayaz, M., Subhan, F., Sadiq, A., Ullah, F., Ahmed, J., \& Sewell, R. D. E. 2017. Cellular efflux transporters and the potential role of natural products in combating efflux mediated drug resistance. Frontiers in Bioscience 22(4): 732-756.

Ball, P. R., Shales, S. W., \& Chopra, I. 1980. Plasmid-mediated tetracycline resistance in Escherichia coli involves increased efflux of the antibiotic. Biochemical and Biophysical Research Communications 93(1): 74-81.

Barbieri, R., Coppo, E., Marchese, A., Daglia, M., SobarzoSanchez, E., Nabavi, S. F., \& Nabavi, S. M. 2017. Phytochemicals for human disease: An update on plantderived compounds antibacterial activity. Microbiological Research 196: 44-68.

Beceiro, A., Tomás, M., \& Bou, G. 2013. Antimicrobial resistance and virulence: A successful or deleterious association in the bacterial world? Clinical Microbiology Reviens 26(2): 185-230.

Begic, S., \& Worobec, E. A. 2006. Regulation of Serratia marcescens ompF and ompC porin genes in response to osmotic stress, salicylate, temperature and $\mathrm{pH}$. Microbiology 152(2): 485-491.

Bevan, E. R., Jones, A. M., \& Hawkey, P. M. 2017. Global epidemiology of CTX-M $\beta$-lactamases: Temporal and geographical shifts in genotype. Journal of Antimicrobial Chemotherapy 72(8): 2145-2155.

Bindiya, E. S., Tina, K. J., Sasidharan, R. S., \& Bhat, S. G. 2019. BaCf3: Highly thermostable bacteriocin from Bacillus amyloliquefaciens BTSS3 antagonistic on food-borne pathogens. 3 Biotech 9(4): 136.

Binh, T. T., Shiota, S., Suzuki, R., Matsuda, M., Trang, T. T. H., Kwon, D. H., Iwatani, S., \& Yamaoka, Y. 2014. Discovery of novel mutations for clarithromycin resistance in Helicobacter pylori by using next-generation sequencing. Journal of Antimicrobial Chemotherapy 69(7): 1796-1803.

Biruksew, A., Zeynudin, A., Alemu, Y., Golassa, L., Yohannes, M., Debella, A., Urge, G., De Spiegeleer, B., \& Suleman, S. 2018. Zingiber officinale roscoe and Echinops kebericho mesfin showed antiplasmodial activities against Plasmodium berghei in a dose-dependent manner in Ethiopia. Ethiopian Journal of Health Sciences 28(5): 655.

Blair, J. M., Webber, M. A., Baylay, A. J., Ogbolu, D. O., \& Piddock, L. J. 2015. Molecular mechanisms of antibiotic resistance. Nature Reviews Microbiology 13(1): 42.

Bohnert, J. A., Schuster, S., Fähnrich, E., Trittler, R., \& Kern, W. V. 2007. Altered spectrum of multidrug resistance associated with a single point mutation in the Escherichia coli RND-type MDR efflux pump YhiV (MdtF). Journal of Antimicrobial Chemotherapy 59(6): 1216-1222.

Brandt, Y. I., Armijo, L. M., Rivera, A. C., Plumley, J. B., Cook, N. C., Smolyakov, G. A., Smyth, H. D., \& Osiński, M. 2013. Effectiveness of tobramycin conjugated to iron oxide nanoparticles in treating infection in cystic fibrosis. Colloidal Nanocrystals for Biomedical Applications VIII 8595: 85951C.

Brown, D. F., \& Reynolds, P. E. 1980. Intrinsic resistance to $\beta$ lactam antibiotics in Staphylococcus aureus. FEBS Letters 122(2): 275-278.

Cao, Hui, Chai, T.-T., Wang, X., Morais-Braga, M. F. B., Yang, J.H., Wong, F.-C., Wang, R., Yao, H., Cao, J., \& Cornara, L. 2017. Phytochemicals from fern species: Potential for medicine applications. Phytochemistry Reviews 16(3): 379-440.

Cao, Huiluo, Xia, T., Li, Y., Xu, Z., Bougouffa, S., Lo, Y. K., Bajic, V. B., Luo, H., Woo, P. C., \& Yan, A. 2019. Uncoupled quorum sensing modulates the interplay of virulence and resistance in a multidrug-resistant clinical Pseudomonas aeruginosa isolate belonging to the MLST550 clonal complex. Antimicrobial Agents and Chemotherapy 63(4): e01944-18.

Chellat, M. F., Raguž, L., \& Riedl, R. 2016. Targeting antibiotic resistance. Angewandte Chemie International Edition 55(23): 6600-6626.

Chewapreecha, C., Marttinen, P., Croucher, N. J., Salter, S. J., Harris, S. R., Mather, A. E., Hanage, W. P., Goldblatt, D., Nosten, F. H., \& Turner, C. 2014. Comprehensive identification of single nucleotide polymorphisms associated with beta-lactam resistance within pneumococcal mosaic genes. PLoS Genetics 10(8): e1004547.

Chuma, T., Miyasako, D., Hesham, D., Takayama, T., Nakamoto, Y., Shahada, F., Akiba, M., \& Okamoto, K. 2013. Chronological change of resistance to $\beta$-lactams in Salmonella enterica serovar infantis isolated from broilers in Japan. Frontiers in Microbiology 4: 113.

Danilchanka, O., Pavlenok, M., \& Niederweis, M. 2008. Role of porins for uptake of antibiotics by Mycobacterium smegmatis. Antimicrobial Agents and Chemotherapy 52(9): 3127-3134.

Dewé, T. C., D'Aeth, J. C., \& Croucher, N. J. 2019. Genomic epidemiology of penicillin-non-susceptible Streptococcus pneumoniae. Microbial Genomics: mgen000305.

Dolejska, M., Villa, L., Poirel, L., Nordmann, P., \& Carattoli, A. 2012. Complete sequencing of an IncHI1 plasmid encoding the carbapenemase NDM-1, the ArmA 16S RNA methylase and a resistance-nodulation-cell division/multidrug efflux pump. Journal of Antimicrobial Chemotherapy 68(1): 34-39.

Domadia, P. N., Bhunia, A., Sivaraman, J., Swarup, S., \& Dasgupta, D. 2008. Berberine targets assembly of Escherichia coli cell division protein FtsZ. Biochemistry 47(10): 3225-3234. 
Dowson, C. G., Hutchison, A., Woodford, N., Johnson, A. P., George, R. C., \& Spratt, B. G. 1990. Penicillin-resistant viridans streptococci have obtained altered penicillinbinding protein genes from penicillin-resistant strains of Streptococcus pneumoniae. Proceedings of the National Academy of Sciences 87(15): 5858-5862.

Editor ISS. Calls to rein in antibiotic use after study shows $65 \%$ increase worldwide. The Guardian. https://www.theguardian.com/science/2018/mar/26/call s-to-rein-in-antibiotic-use-after-study- shows-65-increaseworldwide 26 March 2018. Retrieved 18 June 2019.

Elhadidy, M., Miller, W. G., Arguello, H., Álvarez-Ordóñez, A., Dierick, K., \& Botteldoorn, N. 2019. Molecular epidemiology and antimicrobial resistance mechanisms of Campylobacter coli from diarrhoeal patients and broiler carcasses in Belgium. Transboundary and Emerging Diseases 66(1): 463-475.

Fatholahzadeh, B., Emaneini, M., Feizabadi, M. M., Sedaghat, H., Aligholi, M., Taherikalani, M., \& Jabalameli, F. 2009. Characterisation of genes encoding aminoglycosidemodifying enzymes among meticillin-resistant Staphylococcus aureus isolated from two hospitals in Tehran, Iran. International Journal of Antimicrobial Agents 33(3): 264-265.

Feldberg, R. S., Chang, S. C., Kotik, A. N., Nadler, M., Neuwirth, Z., Sundstrom, D. C., \& Thompson, N. H. 1988. In vitro mechanism of inhibition of bacterial cell growth by allicin. Antimicrobial Agents and Chemotherapy 32(12): 1763-1768.

Fernández, L., \& Hancock, R. E. 2012. Adaptive and mutational resistance: Role of porins and efflux pumps in drug resistance. Clinical Microbiology Reviews 25(4): 661-681.

Fischbach, M. A., \& Walsh, C. T. 2009. Antibiotics for emerging pathogens. Science 325(5944): 1089-1093.

Fisher, J. F., Meroueh, S. O., \& Mobashery, S. 2005. Bacterial resistance to $\beta$-lactam antibiotics: Compelling opportunism, compelling opportunity. Chemical Reviews 105(2): 395-424.

Floyd, J. L., Smith, K. P., Kumar, S. H., Floyd, J. T., \& Varela, M. F. 2010. LmrS is a multidrug efflux pump of the major facilitator superfamily from Staphylococcus aureus. Antimicrobial Agents and Chemotherapy 54(12): 5406-5412.

Fuochi, V., Cardile, V., Petronio Petronio, G., \& Furneri, P. M. 2019. Biological properties and production of bacteriocinslike-inhibitory substances by Lactobacillus sp. strains from human vagina. Journal of Applied Microbiology 126(5): 15411550.

Fuochi, V., Li Volti, G., \& Furneri, P. M. 2017. Commentary: lactobacilli dominance and vaginal $\mathrm{pH}$ : why is the human vaginal microbiome unique? Frontiers in Microbiology 8: 1815.

Galhardo, R. S., Hastings, P. J., \& Rosenberg, S. M. 2007. Mutation as a stress response and the regulation of evolvability. Critical Reviews in Biochemistry and Molecular Biology 42(5): 399435.

García-Fernández, A., Villa, L., Carta, C., Venditti, C., Giordano, A., Venditti, M., Mancini, C., \& Carattoli, A. 2012. Klebsiella pneumoniae ST258 producing KPC-3 identified in Italy carries novel plasmids and OmpK36/OmpK35 porin variants. Antimicrobial Agents and Chemotherapy 56(4): 2143-2145.

Ghosh, A., Singh, A., Ramteke, P. W., \& Singh, V. P. 2000. Characterization of large plasmids encoding resistance to toxic heavy metals in Salmonella abortus equi. Biochemical and Biophysical Research Communications 272(1): 6-11.

Gill, M. J., Simjee, S., Al-Hattawi, K., Robertson, B. D., Easmon, C. S. F., \& Ison, C. A. 1998. Gonococcal resistance to $\beta$ lactams and tetracycline involves mutation in loop 3 of the porin encoded at thepenB locus. Antimicrobial Agents and Chemotherapy 42(11): 2799-2803.
Grimont, P. A. D., \& Grimont, F. 1984. Family I. Enterobacteriaceae. Bergey's Manual of Systematic Bacteriology 1: 1984-477.

Hakenbeck, R., Tarpay, M., \& Tomasz, A. 1980. Multiple changes of penicillin-binding proteins in penicillin-resistant clinical isolates of Streptococcus pneumoniae. Antimicrobial Agents and Chemotherapy 17(3): 364-371.

Hancock, R. E., \& Brinkman, F. S. 2002. Function of Pseudomonas porins in uptake and efflux. Annual Reviews in Microbiology 56(1): 17-38.

Hao, M., Ye, M., Shen, Z., Hu, F., Yang, Y., Wu, S., Xu, X., Zhu, S., Qin, X., \& Wang, M. 2018. Porin Deficiency in carbapenem-resistant Enterobacter aerogenes strains. Microbial Drug Resistance 24(9), 1277-1283.

Hart, C. A., \& Kariuki, S. (1998). Antimicrobial resistance in developing countries. BMJ: British Medical Journal 317 (7159): 647.

Hartman, B. J., \& Tomasz, A. 1984. Low-affinity penicillin-binding protein associated with beta-lactam resistance in Staphylococcus aureus. Journal of Bacteriology 158(2): 513-516.

Hasegawa, K., Yamamoto, K., Chiba, N., Kobayashi, R., Nagai, K., Jacobs, M. R., Appelbaum, P. C., Sunakawa, K., \& Ubukata, K. 2003. Diversity of ampicillin-resistance genes in Haemophilus influenzae in Japan and the United States. Microbial Drug Resistance 9(1): 39-46.

Hegstad, K., Mikalsen, T., Coque, T. M., Werner, G., \& Sundsfjord, A. 2010. Mobile genetic elements and their contribution to the emergence of antimicrobial resistant Enterococcus faecalis and Enterococcus faecium. Clinical Microbiology and Infection 16(6): 541-554.

Heselpoth, R. D., Euler, C. W., Schuch, R., \& Fischetti, V. A. 2019. Lysocins: Bioengineered antimicrobials that deliver lysins across the outer membrane of Gram-negative bacteria. Antimicrobial Agents and Chemotherapy 63(6): e00342-19.

High levels of antibiotic resistance found worldwide, new data shows. Available from: https://www.who.int/newsroom/detail/29-01-2018-high-levels-of-antibioticresistance-found-worldwide-new-data-shows. Cited 18 June 2019

Hochachka, P. W., \& Somero, G. N. 2002. Biochemical adaptation: mechanism and process in physiological evolution. Oxford University Press.

Hong, D. J., Bae, I. K., Jang, I.-H., Jeong, S. H., Kang, H.-K., \& Lee, K. 2015. Epidemiology and characteristics of metallo$\beta$-lactamase-producing Pseudomonas aeruginosa. Infection \& Chemotherapy 47(2): 81-97.

Hoshino, T., Sato, Y., Toyonaga, Y., Hanaki, H., Sunakawa, K., \& Disease, D.-R. P. S. G. in P. I. 2013. Nationwide survey of the development of drug resistance in the pediatric field in 2007 and 2010: Drug sensitivity of Haemophilus influenzae in Japan (second report). Journal of Infection and Chemotherapy 19(3): 495-503.

Hu, R.-M., Liao, S.-T., Huang, C.-C., Huang, Y.-W., \& Yang, T.C. 2012. An inducible fusaric acid tripartite efflux pump contributes to the fusaric acid resistance in Stenotrophomonas maltophilia. PLoS One 7(12): e51053.

Huisman, G. W., \& Kolter, R. 1994. Sensing starvation: A homoserine lactone-dependent signaling pathway in Escherichia coli. Science 265(5171): 537-539.

Ibrahim, M. E. 2019. Prevalence of Acinetobacter baumannii in Saudi Arabia: Risk factors, antimicrobial resistance patterns and mechanisms of carbapenem resistance. Annals of Clinical Microbiology and Antimicrobials 18(1): 1.

Ito, T., Katayama, Y., \& Hiramatsu, K. 1999. Cloning and nucleotide sequence determination of the entire mec DNA of pre-methicillin-resistant Staphylococcus aureus N315. Antimicrobial Agents and Chemotherapy 43(6): 1449-1458. 
Ito, Teruyo, Katayama, Y., Asada, K., Mori, N., Tsutsumimoto, K., Tiensasitorn, C., \& Hiramatsu, K. 2001. Structural comparison of three types of staphylococcal cassette chromosome mec integrated in the chromosome in methicillin-resistant Staphylococcus aureus. Antimicrobial Agents and Chemotherapy 45(5): 1323-1336.

Iwamoto, A., Tanahashi, T., Okada, R., Yoshida, Y., Kikuchi, K., Keida, Y., Murakami, Y., Yang, L., Yamamoto, K., \& Nishiumi, S. 2014. Whole-genome sequencing of clarithromycin resistant Helicobacter pylori characterizes unidentified variants of multidrug resistant efflux pump genes. Gut Pathogens 6(1): 27.

Iyer, R., \& Delcour, A. H. 1997. Complex inhibition of OmpF and OmpC bacterial porins by polyamines. Journal of Biological Chemistry 272(30): 18595-18601.

Jabalameli, F., Taki, E., Emaneini, M., \& Beigverdi, R. 2018. Prevalence of metallo- $\beta$-lactamase-encoding genes among carbapenem-resistant Pseudomonas aeruginosa strains isolated from burn patients in Iran. Revista Da Sociedade Brasileira de Medicina Tropical 51(3): 270-276.

Jacoby, G. A., \& Munoz-Price, L. S. 2005. The new $\beta$-lactamases. New England Journal of Medicine 352(4): 380-391.

Jeters, R. T., Wang, G.-R., Moon, K., Shoemaker, N. B., \& Salyers, A. A. 2009. Tetracycline-associated transcriptional regulation of transfer genes of the Bacteroides conjugative transposon CTnDOT. Journal of Bacteriology 191(20): 63746382.

Katayama, Y., Ito, T., \& Hiramatsu, K. 2000. A new class of genetic element, staphylococcus cassette chromosome mec, encodes methicillin resistance in Staphylococcus aureus. Antimicrobial Agents and Chemotherapy 44(6): 1549-1555.

Keeney, D., Ruzin, A., McAleese, F., Murphy, E., \& Bradford, P. A. 2008. MarA-mediated overexpression of the AcrAB efflux pump results in decreased susceptibility to tigecycline in Escherichia coli. Journal of Antimicrobial Chemotherapy 61(1): 46-53.

Kennedy, S. P., Ng, W. V., Salzberg, S. L., Hood, L., \& DasSarma, S. 2001. Understanding the adaptation of Halobacterium species NRC-1 to its extreme environment through computational analysis of its genome sequence. Genome Research 11(10): 1641-1650.

Khan, S. A., Nawaz, M. S., Khan, A. A., \& Cerniglia, C. E. 1999. Simultaneous detection of erythromycin-resistant methylase genes ermA and ermC from Staphylococcus spp. by multiplex-PCR. Molecular and Cellular Probes 13(5): 381-387.

Kim, C., Mwangi, M., Chung, M., Milheirço, C., de Lencastre, H., \& Tomasz, A. 2013. The mechanism of heterogeneous beta-lactam resistance in MRSA: Key role of the stringent stress response. PLoS One 8(12): e82814.

Klančnik, A., Šikić Pogačar, M., Trošt, K., Tušek Žnidarič, M., Mozetič Vodopivec, B., \& Smole Možina, S. 2017. AntiCampylobacter activity of resveratrol and an extract from waste Pinot noir grape skins and seeds, and resistance of Camp. jejuni planktonic and biofilm cells, mediated via the Cme ABC efflux pump. Journal of Applied Microbiology 122(1): 65-77.

Kojima, S., \& Nikaido, H. 2013. Permeation rates of penicillins indicate that Escherichia coli porins function principally as nonspecific channels. Proceedings of the National Academy of Sciences 110(28): E2629-E2634.

Kokoska, L., Kloucek, P., Leuner, O., \& Novy, P. 2019. Plantderived products as antibacterial and antifungal agents in human health care. Current Medicinal Chemistry.

Kong, H.-K., Pan, Q., Lo, W.-U., Liu, X., Law, C. O., Chan, T., Ho, P.-L., \& Lau, T. C.-K. 2018. Fine-tuning carbapenem resistance by reducing porin permeability of bacteria activated in the selection process of conjugation. Scientific Reports 8(1): 15248.
Korte-Berwanger, M., Sakinc, T., Kline, K., Nielsen, H. V., Hultgren, S., \& Gatermann, S. G. 2013. Significance of the $\mathrm{D}$-serine-deaminase and D-serine metabolism of Staphylococcus saprophyticus for virulence. Infection and Immunity 81(12): 4525-4533.

Kuroda, M., Ohta, T., Uchiyama, I., Baba, T., Yuzawa, H., Kobayashi, I., Cui, L., Oguchi, A., Aoki, K., \& Nagai, Y. 2001. Whole genome sequencing of methicillin-resistant Staphylococcus aureus. The Lancet 357 (9264): 1225-1240.

Kushner, D. J. 1978. Microbial life in extreme environments. Academic Press.

Lambert, P. A. 2002. Cellular impermeability and uptake of biocides and antibiotics in Gram-positive bacteria and mycobacteria. Journal of Applied Microbiology 92: 46S-54S.

Lambert, Peter A. 2005. Bacterial resistance to antibiotics: Modified target sites. Advanced Drug Delivery Reviews 57(10): 1471-1485.

Lanzotti, V., Scala, F., \& Bonanomi, G. 2014. Compounds from Allium species with cytotoxic and antimicrobial activity. Phytochemistry Reviews 13(4): 769-791.

LeBel, G., Vaillancourt, K., Bercier, P., \& Grenier, D. 2019. Antibacterial activity against porcine respiratory bacterial pathogens and in vitro biocompatibility of essential oils. Archives of Microbiology: 1-8.

Lebreton, F., Depardieu, F., Bourdon, N., Fines-Guyon, M., Berger, P., Camiade, S., Leclercq, R., Courvalin, P., \& Cattoir, V. 2011. D-Ala-D-Ser VanN-type transferable vancomycin resistance in Enterococcus faecium. Antimicrobial Agents and Chemotherapy 55(10): 4606-4612.

Lechner, D., Gibbons, S., \& Bucar, F. 2008. Plant phenolic compounds as ethidium bromide efflux inhibitors in Mycobacterium smegmatis. Journal of Antimicrobial Chemotherapy 62(2): 345-348.

Leclercq, R. 2002. Mechanisms of resistance to macrolides and lincosamides: Nature of the resistance elements and their clinical implications. Clinical Infectious Diseases 34(4): 482 492.

Levin, B. R., Perrot, V., \& Walker, N. 2000. Compensatory mutations, antibiotic resistance and the population genetics of adaptive evolution in bacteria. Genetics 154(3): 985-997.

Levy, S. B., \& McMurry, L. 1978. Plasmid-determined tetracycline resistance involves new transport systems for tetracycline. Nature 276(5683): 90.

Li, B., \& Webster, T. J. 2018. Bacteria antibiotic resistance: New challenges and opportunities for implant-associated orthopedic infections. Journal of Orthopaedic Research 36(1): 22-32.

Ling, J. M., Chan, E. W., Lam, A. W., \& Cheng, A. F. 2003. Mutations in topoisomerase genes of fluoroquinoloneresistant salmonellae in Hong Kong. Antimicrobial Agents and Chemotherapy 47(11): 3567-3573.

Liu, B., \& Pop, M. (2008). ARDB-antibiotic resistance genes database. Nucleic Acids Research 37(suppl_1): D443-D447.

Long, K. S., Poehlsgaard, J., Kehrenberg, C., Schwarz, S., \& Vester, B. 2006. The Cfr rRNA methyltransferase confers resistance to phenicols, lincosamides, oxazolidinones, pleuromutilins, and streptogramin A antibiotics. Antimicrobial Agents and Chemotherapy 50(7): 2500-2505.

Maciá, M. D., Blanquer, D., Togores, B., Sauleda, J., Pérez, J. L., \& Oliver, A. 2005. Hypermutation is a key factor in development of multiple-antimicrobial resistance in Pseudomonas aeruginosa strains causing chronic lung infections. Antimicrobial Agents and Chemotherapy 49(8): 33823386.

Martinez, J. L., \& Baquero, F. 2000. Mutation frequencies and antibiotic resistance. Antimicrobial Agents and Chemotherapy 44(7): 1771-1777. 
Masi, M., \& Pagès, J.-M. 2013. Suppl 1: Structure, function and regulation of outer membrane proteins involved in drug transport in Enterobactericeae: the $\mathrm{OmpF} / \mathrm{C}-\mathrm{TolC}$ Case. The Open Microbiology Journal 7: 22.

Massova, I., \& Mobashery, S. 1998. Kinship and diversification of bacterial penicillin-binding proteins and $\beta$-lactamases. Antimicrobial Agents and Chemotherapy 42(1): 1-17.

Mathers, A. J., Peirano, G., \& Pitout, J. D. 2015. The role of epidemic resistance plasmids and international high-risk clones in the spread of multidrug-resistant Enterobacteriaceae. Clinical Microbiology Reviews 28(3): 565591.

Matta, A. J., Zambrano, D. C., \& Pazos, A. J. 2018. Punctual mutations in 23S rRNA gene of clarithromycin-resistant Helicobacter pylori in Colombian populations. World Journal of Gastroenterology 24(14): 1531.

McManus, M. C. 1997. Mechanisms of bacterial resistance to antimicrobial agents. American Journal of Health-System Pharmacy 54(12): 1420-1433.

McMurry, L., Petrucci, R. E., \& Levy, S. B. 1980. Active efflux of tetracycline encoded by four genetically different tetracycline resistance determinants in Escherichia coli. Proceedings of the National Academy of Sciences 77(7): 3974-3977.

Mine, T., Morita, Y., Kataoka, A., Mizushima, T., \& Tsuchiya, T. 1999. Expression in Escherichia coli of a new multidrug efflux pump, MexXY, from Psendomonas aeruginosa. Antimicrobial Agents and Chemotherapy 43(2): 415-417.

Mitchell, A., Romano, G. H., Groisman, B., Yona, A., Dekel, E., Kupiec, M., Dahan, O., \& Pilpel, Y. 2009. Adaptive prediction of environmental changes by microorganisms. Nature 460(7252): 220.

Mühlen, S., \& Dersch, P. 2015. Anti-virulence strategies to target bacterial infections. In How to Overcome the Antibiotic Crisis (pp. 147-183). Springer.

Munita, J. M., \& Arias, C. A. 2016. Mechanisms of antibiotic resistance. Microbiology Spectrum 4(2).

Nabu, S., Lawung, R., Isarankura-Na-Ayudhya, P., Roytrakul, S., Dolprasit, S., Sengyee, S., Isarankura-Na-Ayudhya, C., \& Prachayasittikul, V. 2017. Comparative proteomics analysis of Neisseria gonorrboeae strains in response to extendedspectrum cephalosporins. EXCLI Journal 16: 1207.

Nakae, T. 1976. Identification of the outer membrane protein of E. coli that produces transmembrane channels in reconstituted vesicle membranes. Biochemical and Biophysical Research Communications 71(3): 877-884.

Naser, S. A., Sagramsingh, S. R., Naser, A. S., \& Thanigachalam, S. 2014. Mycobacterium avium subspecies paratuberculosis causes Crohn's disease in some inflammatory bowel disease patients. World Journal of Gastroenterology: WJG 20(23): 7403.

Nejabatdoust, A., Zamani, H., \& Salehzadeh, A. 2019. Functionalization of $\mathrm{ZnO}$ nanoparticles by glutamic acid and conjugation with thiosemicarbazide alters expression of efflux pump genes in multiple drug-resistant Staphylococcus aureus strains. Microbial Drug Resistance.

Nikaido, H. 1994. Prevention of drug access to bacterial targets: Permeability barriers and active efflux. Science 264(5157): 382-388.

Ogawa, W., Onishi, M., Ni, R., Tsuchiya, T., \& Kuroda, T. 2012. Functional study of the novel multidrug efflux pump KexD from Klebsiella pneumoniae. Gene 498(2): 177-182.

Oikarainen, P. E., Pohjola, L. K., Pietola, E. S., \& Heikinheimo, A. 2019. Direct vertical transmission of ESBL/pAmpCproducing Escherichia coli limited in poultry production pyramid. Veterinary Microbiology 231: 100-106.

Olesky, M., Hobbs, M., \& Nicholas, R. A. 2002. Identification and analysis of amino acid mutations in porin IB that mediate intermediate-level resistance to penicillin and tetracycline in
Neisseria gonorrboeae. Antimicrobial Agents and Chemotherapy 46(9): 2811-2820.

Olesky, M., Zhao, S., Rosenberg, R. L., \& Nicholas, R. A. 2006. Porin-mediated antibiotic resistance in Neisseria gonorrboeae: Ion, solute, and antibiotic permeation through PIB proteins with penB mutations. Journal of Bacteriology 188(7): 2300 2308.

Öncül, N., \& Yıldırım, Z. 2019. Inhibitory effect of bacteriocins against Escherichia coli O157: H7. Food Science and Technology International: 1082013219840462

Orchard, A., Viljoen, A., \& van Vuuren, S. 2018. Wound pathogens: Investigating antimicrobial activity of commercial essential oil combinations against reference strains. Chemistry \& Biodiversity 15(12): e1800405.

Ouyang, Y., Andersson, C. R., Kondo, T., Golden, S. S., \& Johnson, C. H. 1998. Resonating circadian clocks enhance fitness in cyanobacteria. Proceedings of the National Academy of Sciences 95(15): 8660-8664.

Palmer, K. L., Kos, V. N., \& Gilmore, M. S. 2010. Horizontal gene transfer and the genomics of enterococcal antibiotic resistance. Current Opinion in Microbiology 13(5): 632-639.

Pomposiello, P. J., \& Demple, B. 2000. Identification of SoxSRegulated genes in Salmonella enterica serovar typhimurium. Journal of Bacteriology 182(1): 23-29.

Poole, K. 2011. Pseudomonas aeruginosa: Resistance to the max. Frontiers in Microbiology 2: 65.

Poole, K., Krebes, K., McNally, C., \& Neshat, S. 1993. Multiple antibiotic resistance in Pseudomonas aeruginosa: Evidence for involvement of an efflux operon. Journal of Bacteriology 175(22): 7363-7372.

Pu, X.-Y., Pan, J.-C., Wang, H.-Q., Zhang, W., Huang, Z.-C., \& Gu, Y.-M. 2009. Characterization of fluoroquinoloneresistant Shigella flexneri in Hangzhou area of China. Journal of Antimicrobial Chemotherapy 63(5): 917-920.

Rafińska, K., Pomastowski, P., \& Buszewski, B. 2019. Study of Bacillus subtilis response to different forms of silver. Science of The Total Environment 661: 120-129.

Rakoff-Nahoum, S., Paglino, J., Eslami-Varzaneh, F., Edberg, S., \& Medzhitov, R. 2004. Recognition of commensal microflora by toll-like receptors is required for intestinal homeostasis. Cell 118(2): 229-241.

Ram, R. J., VerBerkmoes, N. C., Thelen, M. P., Tyson, G. W., Baker, B. J., Blake, R. C., Shah, M., Hettich, R. L., \& Banfield, J. F. 2005. Community proteomics of a natural microbial biofilm. Science 308(5730): 1915-1920.

Ranotkar, S., Kumar, P., Zutshi, S., Prashanth, K. S., Bezbaruah, B., Anand, J., \& Lahkar, M. 2014. Vancomycin-resistant enterococci: Troublemaker of the 21st century. Journal of Global Antimicrobial Resistance 2(4): 205-212.

Rao, K. N., \& Venkatachalam, S. R. 2000. Inhibition of dihydrofolate reductase and cell growth activity by the phenanthroindolizidine alkaloids pergularinine and tylophorinidine: The in vitro cytotoxicity of these plant alkaloids and their potential as antimicrobial and anticancer agents. Toxicology in Vitro 14(1): 53-59.

Reiter, J., Levina, N., van der Linden, M., Gruhlke, M., Martin, C., \& Slusarenko, A. 2017. Diallylthiosulfinate (allicin), a volatile antimicrobial from garlic (Allium sativum), kills human lung pathogenic bacteria, including MDR strains, as a vapor. Molecules 22(10): 1711 .

Ribeiro, A. M. B., de Sousa, J. N., Costa, L. M., de Alcântara Oliveira, F. A., dos Santos, R. C., Nunes, A. S. S., ... \& Kaatz, G. W. 2019. Antimicrobial activity of Phyllantbus amarus Schumach. \& Thonn and inhibition of the NorA efflux pump of Staphylococcus aureus by Phyllanthin. Microbial pathogenesis 130: 242-246.

Salmi, C., Loncle, C., Vidal, N., Letourneux, Y., Fantini, J., Maresca, M., Taïeb, N., Pagès, J.-M., \& Brunel, J. M. 2008. 
Squalamine: An appropriate strategy against the emergence of multidrug resistant gram-negative bacteria? PLoS One 3(7): e2765.

Sanders, C. C., \& Sanders Jr, W. E. 1992. $\beta$-Lactam resistance in gram-negative bacteria: Global trends and clinical impact. Clinical Infectious Diseases 15(5): 824-839.

Savoia, D. 2012. Plant-derived antimicrobial compounds: Alternatives to antibiotics. Future Microbiology 7(8): 979-990.

Sewage reveals levels of antimicrobial resistance worldwide. Technical University of Denmark. www.sciencedaily.com/releases/2019/03/190308080513. 8 March 2019. ScienceDaily. Retrieved 17 June 2019. Cited 18 June 2019.

Seyedi-Marghaki, F., Kalantar-Neyestanaki, D., Saffari, F., Hosseini-Nave, H., \& Moradi, M. 2019. Distribution of aminoglycoside-modifying enzymes and molecular analysis of the coagulase gene in clinical isolates of methicillinresistant and methicillin-susceptible Staphylococcus aureus. Microbial Drug Resistance 25(1): 47-53.

Shen, Z., Ding, B., Ye, M., Wang, P., Bi, Y., Wu, S., Xu, X., Guo, Q., \& Wang, M. 2017. High ceftazidime hydrolysis activity and porin OmpK35 deficiency contribute to the decreased susceptibility to ceftazidime/avibactam in KPC-producing Klebsiella pneumoniae. Journal of Antimicrobial Chemotherapy 72(7): 1930-1936.

Shenagari, M., Bakhtiari, M., Mojtahedi, A., \& Roushan, Z. A. 2018. High frequency of mutations in gyrA gene associated with quinolones resistance in uropathogenic Escherichia coli isolates from the north of Iran. Iranian Journal of Basic Medical Sciences 21(12): 1226.

Shore, A. C., Deasy, E. C., Slickers, P., Brennan, G., O'Connell, B., Monecke, S., Ehricht, R., \& Coleman, D. C. 2011. Detection of staphylococcal cassette chromosome mec type XI carrying highly divergent mecA, mecI, mecR1, blaZ, and ccr genes in human clinical isolates of clonal complex 130 methicillin-resistant Staphylococcus aureus. Antimicrobial Agents and Chemotherapy 55(8): 3765-3773.

Silhavy, T. J., Kahne, D., \& Walker, S. 2010. The bacterial cell envelope. Cold Spring Harbor Perspectives in Biology: a000414.

Simoes, M., Bennett, R. N., \& Rosa, E. A. 2009. Understanding antimicrobial activities of phytochemicals against multidrug resistant bacteria and biofilms. Natural Product Reports 26(6): 746-757.

Singh, D., \& Chaudhuri, P. K. 2018. A review on phytochemical and pharmacological properties of Holy basil (Ocimum sanctum L.). Industrial Crops and Products 118: 367-382.

Sobolewska, D., Podolak, I., \& Makowska-Was, J. 2015. Allium ursinum: Botanical, phytochemical and pharmacological overview. Phytochemistry Reviews 14(1): 81-97.

Tachedjian, G., Aldunate, M., Bradshaw, C. S., \& Cone, R. A. 2017. The role of lactic acid production by probiotic lactobacillus species in vaginal health. Research in Microbiology 168(9-10): 782-792.

"Tackling drug-resistant infections globally: final report and recommendations" (pdf). Amr-review.org/.Archived(PDF)

Tamber, S., \& Hancock, R. E. 2003. On the mechanism of solute uptake in Pseudomonas. Frontiers in Biosciences 8: s472-s483.

Taneja, N., Mishra, A., Kumar, A., Verma, G., \& Sharma, M. 2015. Enhanced resistance to fluoroquinolones in laboratorygrown mutants \& clinical isolates of Shigella due to synergism between efflux pump expression $\&$ mutations in quinolone resistance determining region. The Indian Journal of Medical Research 141(1): 81.

Tang, Y., Sahin, O., Pavlovic, N., LeJeune, J., Carlson, J., Wu, Z., Dai, L., \& Zhang, Q. 2017. Rising fluoroquinolone resistance in Campylobacter isolated from feedlot cattle in the United States. Scientific Reports 7(1): 494.
Tenover, F. C. 2006. Mechanisms of antimicrobial resistance in bacteria. The American Journal of Medicine 119(6): S3-S10.

Thanassi, D. G., Cheng, L. W., \& Nikaido, H. 1997. Active efflux of bile salts by Escherichia coli. Journal of Bacteriology 179(8): 2512-2518.

Thorsing, M., Klitgaard, J. K., Atilano, M. L., Skov, M. N., Kolmos, H. J., Filipe, S. R., \& Kallipolitis, B. H. 2013. Thioridazine induces major changes in global gene expression and cell wall composition in methicillin-resistant Staphylococcus aureus USA300. PloS One 8(5): e64518.

Toba, S., Minato, Y., Kondo, Y., Hoshikawa, K., Minagawa, S., Komaki, S., Kumagai, T., Matoba, Y., Morita, D., \& Ogawa, W. 2019. Comprehensive analysis of resistance-nodulationcell division superfamily (RND) efflux pumps from Serratia marcescens, Db10. Scientific Reports 9(1): 4854.

Trias, J., \& Nikaido, H. 1990. Outer membrane protein D2 catalyzes facilitated diffusion of carbapenems and penems through the outer membrane of Pseudomonas aeruginosa. Antimicrobial Agents and Chemotherapy 34(1): 52-57.

Tseng, T.-T., Gratwick, K. S., Kollman, J., Park, D., Nies, D. H., Goffeau, A., \& Saier Jr, M. H. 1999. The RND permease superfamily: An ancient, ubiquitous and diverse family that includes human disease and development proteins. Journal of Molecular Microbiology and Biotechnology 1(1): 107-125.

Tyagi, P., Singh, M., Kumari, H., Kumari, A., \& Mukhopadhyay, K. 2015. Bactericidal activity of curcumin I is associated with damaging of bacterial membrane. PloS One 10(3): e0121313.

Unemo, M., Golparian, D., Nicholas, R., Ohnishi, M., Gallay, A., \& Sednaoui, P. 2012. High-level cefixime-and ceftriaxoneresistant Neisseria gonorrboeae in France: Novel penA mosaic allele in a successful international clone causes treatment failure. Antimicrobial Agents and Chemotherapy 56(3): 1273 1280.

Utsui, Y., \& Yokota, T. 1985. Role of an altered penicillin-binding protein in methicillin-and cephem-resistant Staphylococcus aureus. Antimicrobial Agents and Chemotherapy 28(3): 397-403.

van Hoek, A. H., Mevius, D., Guerra, B., Mullany, P., Roberts, A. P., \& Aarts, H. J. 2011. Acquired antibiotic resistance genes: An overview. Frontiers in Microbiology 2: 203.

Vargiu, A. V., \& Nikaido, H. 2012. Multidrug binding properties of the AcrB efflux pump characterized by molecular dynamics simulations. Proceedings of the National Academy of Sciences 109(50): 20637-20642.

Vega, A. D., \& Delcour, A. H. 1996. Polyamines decrease Escherichia coli outer membrane permeability. Journal of Bacteriology 178(13): 3715-3721.

Weber, P., Meziane-Cherif, D., Haouz, A., Saul, F. A., \& Courvalin, P. 2009. Crystallization and preliminary X-ray analysis of a D-Ala: D-Ser ligase associated with VanG-type vancomycin resistance. Acta Crystallographica Section F: Structural Biology and Crystallization Communications 65(10): 1024-1026.

"WHO publishes list of bacteria for which new antibiotics are urgently needed". http://www.who.int/newsroom/detail/27-02-2017-who-publishes-list-of-bacteriafor-which-new-antibiotics-are-urgently-needed 27 February 2017. Cited 27 October 2018.

Woelfle, M. A., Ouyang, Y., Phanvijhitsiri, K., \& Johnson, C. H. 2004. The adaptive value of circadian clocks: An experimental assessment in cyanobacteria. Current Biology 14(16): 1481-1486.

World Health Organization (Ed.). 2014. Antimicrobial resistance: Global report on surveillance. World Health Organization.

Wright, G. D. 2005. Bacterial resistance to antibiotics: Enzymatic degradation and modification. Advanced Drug Delivery Reviews 57(10): 1451-1470. 
Xiao, J. 2017. Dietary flavonoid aglycones and their glycosides: Which show better biological significance? Critical Reviews in Food Science and Nutrition 57(9): 1874-1905.

Xu, Z., Chen, L., Xiao, Z., Zhu, Y., Jiang, H., Jin, Y., Gu, C., Wu, Y., Wang, L., \& Zhang, W. 2018. Potentiation of the anticancer effect of doxorubicinin drug-resistant gastric cancer cells by tanshinone IIA. Phytomedicine 51: 58-67.

Yao, W., Xu, G., Li, D., Bai, B., Wang, H., Cheng, H., Zheng, J., Sun, X., Lin, Z., \& Deng, Q. 2019. Staphylococcus aureus with an erm-mediated constitutive macrolide-lincosamidestreptogramin B resistance phenotype has reduced susceptibility to the new ketolide, solithromycin. $B M C$ Infectious Diseases 19(1): 175.

Yi, Z.-B., Yu, Y., Liang, Y.-Z., \& Zeng, B. 2007. Evaluation of the antimicrobial mode of berberine by LC/ESI-MS combined with principal component analysis. Journal of Pharmaceutical and Biomedical Analysis 44(1): 301-304.

Zhang, H., Zheng, L., Zhao, J., Ding, S., \& Xia, Y. 2019. Investigation of fluoroquinolone resistance mechanism in Mycoplasma hominis isolated from urogenital samples in a Chinese hospital. Journal of Medical Microbiology 68(2): 206210.

Zhang, W.-J., Xu, X.-R., Schwarz, S., Wang, X.-M., Dai, L., Zheng, H.-J., \& Liu, S. 2013. Characterization of the IncA/C plasmid pSCEC2 from Escherichia coli of swine origin that harbours the multiresistance gene cfr. Journal of Antimicrobial Chemotherapy 69(2): 385-389.

Zhao, C., Wu, Y., Liu, X., Liu, B., Cao, H., Yu, H., Sarker, S. D., Nahar, L., \& Xiao, J. 2017. Functional properties, structural studies and chemo-enzymatic synthesis of oligosaccharides. Trends in Food Science \& Technology 66: 135-145.

Zhao, W.-H., \& Hu, Z.-Q. 2013. Epidemiology and genetics of CTX-M extended-spectrum $\beta$-lactamases in Gram-negative bacteria. Critical Reviews in Microbiology 39(1): 79-101.

Zighelboim, S., \& Tomasz, A. 1980. Penicillin-binding proteins of multiply antibiotic-resistant South African strains of Streptococcus pneumoniae. Antimicrobial Agents and Chemotherapy 17(3): 434-442.

Zou, D., Xie, K., Wang, H., Chen, Y., \& Xie, M. 2014. Inhibitory effects of biochanin A on the efflux pump of methicillinresistant Staphylococcus aureus (MRSA). Wei Sheng Wu Xue Bao=Acta Microbiologica Sinica 54(10): 1204-1211. 